\title{
Plankton dynamics in frontal systems of the Southern Ocean
}

\author{
Inga Hense *, Ulrich V. Bathmann, Ralph Timmermann \\ Alfred-Wegener-Institut für Polar- und Meeresforschung, Postfach 120161, D-27515 Bremerhaven, Germany
}

Received 9 February 1999; accepted 3 May 2000

\begin{abstract}
A Biological Model of the Antarctic Polar Front (BIMAP) has been developed. The model comprises two biochemical cycles, silica and nitrogen, and five to seven compartments. Model runs are initialized using the WOCE data set and forced by an annual cycle of solar radiation and mixed layer depth. Sensitivity experiments indicate that disregarding remineralization and dissolution of silica does not affect phyto- and zooplankton biomass significantly. Experiments with different half saturation constants of silicate uptake indicate that values between 4 and 8 are reasonable for the plankton community at the Antarctic Polar Front. The role of iron limitation is investigated using different Si:N uptake ratios and reduced growth rates. While reducing the maximum growth rate leads only to slightly lower phyto- and zooplankton biomasses, different Si:N uptake ratios affect the development and maximum of plankton biomass significantly. Specifically, primary production and plankton biomass are strongly reduced by increasing the silica to nitrogen uptake ratio to values greater than 2. An Si:N uptake ratio between 2 and 4 appears to be reasonable for the region of the Polar Front. (c) 2000 Elsevier Science B.V. All rights reserved.
\end{abstract}

Keywords: plankton model; frontal system; silica and nitrogen; uptake ratio; iron limitation

\section{Introduction}

Although the Southern Ocean is rich in nutrients, phytoplankton biomass is generally low. Hence, the Southern Ocean is one of the three large high nutrient low chlorophyll (HNLC) areas. In contrast to this, the Antarctic Polar Front is characterized by high phytoplankton biomass ( $\mathrm{Chl} a$ concentrations from 2 up to $4.5 \mu \mathrm{g}^{-1}$ ), highlighting this region as an exceptional zone with frequent plankton blooms

\footnotetext{
* Corresponding author. Tel.: +49-4831-1752; Fax: +49-48311797.

E-mail address: ihense@awi-bremerhaven.de (I. Hense).
}

in the ambient HNLC area (Smetacek et al., 1997). Although numerous expeditions have been carried out in this region, (e.g., Hart, 1934; Dafner and Mordasova, 1994; Fronemann et al., 1995; Bathmann et al., 1997) the factors controlling phytoplankton blooms in this area remain uncertain. Besides possible limitation of light due to a deep mixed layer south of the frontal region, grazing and also possible limitation of micronutrients have been considered:

- Smetacek and Passow (1990) reevaluated the investigations of Sverdrup (1953) and Sakshaug and Holm-Hansen (1984) and proposed that phytoplankton blooms will only develop in a mixed layer less than $40 \mathrm{~m}$ deep. In the region of the Polar Front 
favourable physical conditions may enhance phytoplankton growth: Strong upwelling in frontal regions is linked to a shallow mixed layer and a higher supply of nutrients in the euphotic zone (Veth et al., 1997).

- While grazing of zooplankton and of swarm organisms like salps could inhibit the build-up of phytoplankton blooms in vast areas of the Southern Ocean (Dubischar and Bathmann, 1997), swarm organisms are generally not present in the region of the Polar Front (Foxton, 1966).

- Iron concentration is generally low in the Southern Ocean and may limit the growth rate of phytoplankton (e.g., Gran, 1931; Martin and Fitzwater, 1988; de Baar, 1994). Higher iron concentration in the region of the Polar Front coincided with the development of a phytoplankton bloom in 1992 (De Baar et al., 1995).

Furthermore, in some regions of the Southern Ocean silicate concentration is low $(<10 \mu \mathrm{mol} / \mathrm{l})$. Measured half saturation constants of silica uptake range between 1.1 (Nelson and Tréguer, 1992) and $88.7 \mu \mathrm{mol} / 1$ (Sommer, 1986), which have implications on silica consumption and therefore on diatom growth. In the region of the Polar Front, the bloom forming phytoplankter are large-celled or longchained diatom species (e.g., Fragilariopsis kerguelensis, Corethron criophilum, Thalassiothrix sp.) whose growth rate might be limited by low silicate concentrations (Tréguer and Jacques, 1992; Nelson and Tréguer, 1992; Dafner and Mordasova, 1994; Quéguiner et al., 1997). Non-Si requiring phytoplankton occurs only in low concentrations and diatoms clearly dominate the plankton community in the region of the Polar Front (e.g., Laubscher et al., 1993; Smetacek et al., 1997; Bracher et al., 1999). The smaller size class of the plankton community which consist of pico- and nanoplankton can be characterized by a low and stable biomass of maximum concentrations of $0.2 \mu \mathrm{g} \mathrm{Chl} a / 1$ (Smetacek, 1999).

To study the processes stimulating and controlling phytoplankton blooms in the Southern Ocean, a Biological Model for the Antarctic Polar Front (BIMAP) was developed. BIMAP is a hierarchy of models with different complexity. Zero-dimensional model runs are intended to accompany and prepare three-dimensional (3D) model runs, as they are computation- ally cheap and allow for a larger number of sensitivity studies.

Questions that need to be addressed include the following.

1. How is phytoplankton growth affected by silica enrichment in diatom frustules?

Traditionally, the uptake ratio of silica to nitrogen was regarded as 1. Even in a couple of diatom species, Brzezinski (1985) recorded an Si:C ratio of 0.13 and an Si:N ratio of 1 . However, recent studies recorded an $\mathrm{Si}: \mathrm{N}$ ratio of 4 or an $\mathrm{Si}: \mathrm{C}$ ratio of 0.6 in the Southern Ocean plankton community (Nelson and Smith, 1986; Shiomoto and Ishii, 1995; Hense et al., 1998). Consistent with that is an Si:N uptake ratio or "disappearance ratio" of about 4 in that region (Minas and Minas, 1992; Dafner and Mordasova, 1994; Hense et al., 1998), explained by heavily silicified diatoms or a faster regeneration of nitrogen than of silica after a bloom decay.

2. Is phytoplankton growth limited by a deficiency of micronutrients like iron?

Besides the already mentioned direct reduction of phytoplankton growth rates, Hutchins and Bruland (1998) as well as Takeda (1998) pointed out that iron deficiency may lead to a silica enrichment in diatoms. As this would affect the $\mathrm{Si}: \mathrm{N}$ uptake ratio, it might lead to a depletion of dissolved silicate and thus, subsequently, to further nutrient limitation of phytoplankton growth. Thus, iron limitation and variations in the $\mathrm{Si} \mathrm{N}$ uptake ratio appear to be related issues.

3. How does hydrography affect the ecosystem at the Polar Front? Or, more specifically, what is the effect of different annual cycles of the mixed layer depth on the development of phytoplankton blooms?

In this paper, we present a series of experiments with a vertically integrated model which are intended to be a first approach to answering these questions.

\section{Model description}

\subsection{Prognostic variables}

BIMAP comprises two biochemical cycles. Following Fasham et al. (1990), nitrogen is distributed 
between the phyto- and zooplankton pools and the nutrients nitrate and ammonium. As the model is supposed to reflect the plankton community in the Antarctic Polar Front, we complemented this by a silica cycle. The two cycles are coupled by a constant $\mathrm{Si}: \mathrm{N}$ uptake ratio for phytoplankton growth.

Thus, our standard model comprises the five compartments phytoplankton (P), zooplankton (Z), nitrate $\left(\mathrm{N}_{\mathrm{i}}\right)$, ammonium $\left(\mathrm{N}_{\mathrm{a}}\right)$ and silicate $\left(\mathrm{S}_{\mathrm{i}}\right)$. Sensitivity experiments investigating the effect of remineralization of detritus and dissolution of silica are performed including the two additional compartments $\operatorname{Det}_{\mathrm{N}}$ and Det $\mathrm{Si}_{\mathrm{S}}$, which comprise the nitrogen and silica part of detritus, respectively. Biomass in these compartments is computed in mmol $\mathrm{N} \mathrm{m}^{-3}$ and $\mathrm{mmol} \mathrm{Si} \mathrm{m}^{-3}$, respectively. We assume a C:Chl $a$ ratio of 50. Conversion from carbon to nitrogen units is done using the Redfield ratio.

We decided to disregard the dissolved organic nitrogen (DON) as there still is some uncertainty about the role of DON. Only the labile substances are known and these are remineralized rapidly thus, we directly lead the DON exuded by phytoplankton into the ammonium pool.

\subsubsection{Phytoplankton}

Following Fasham et al. (1990), temporal changes of the phytoplankton concentration are due to primary production, grazing by zooplankton, natural mortality and effects of mixing:

$$
\frac{\mathrm{dP}}{\mathrm{d} t}=(1-\gamma) \sigma \mathrm{P}-g_{\mathrm{Z}}-\mu_{\mathrm{P}} \mathrm{P}+D_{\mathrm{P}}
$$

The growth rate $\sigma$ considers the maximum (light dependent) growth rate $\omega$ and a limitation by nutrients $\eta$. We will further call it the actual growth rate: $\sigma=\omega \eta$. The biomass, which is exuded as DON during the cell division, is $\gamma \sigma$. Following Williams (1990) who suggested that $1 / 20$ of the phytoplankton primary production will be exuded, we choose $\gamma=0.05 . g_{z}$ indicates the losses by grazing through zooplankton, represented by herbivorous copepods. $\mu_{\mathrm{P}}$ represents the mortality of phytoplankton which we assume to be 0.05 as natural mortality is quite low for Antarctic species (Peters and Thomas, 1996).
$D_{\mathrm{P}}$ represents the effects of entrainment, detrainment and diffusion over the pycnocline.

Following the law of minimum of Liebig (1840), the nutrient limited growth rate for diatoms considers possible limitation either by nitrate or by silicate:

$\eta=\min \left(\frac{\mathrm{N}_{\mathrm{i}}}{k_{\mathrm{N}_{\mathrm{i}}}+\mathrm{N}_{\mathrm{i}}}, \frac{\mathrm{S}_{\mathrm{i}}}{k_{\mathrm{S}_{\mathrm{i}}}+\mathrm{S}_{\mathrm{i}}}\right)$

Basically, a Michaelis-Menten type relation is assumed for all nutrients using the half saturation constants $k_{\mathrm{S}_{\mathrm{i}}}$ and $k_{\mathrm{N}_{\mathrm{i}}}$. For nitrate, we chose a $k_{\mathrm{N}_{\mathrm{i}}}=$ $0.3 \mathrm{mmol} \mathrm{N} \mathrm{m}{ }^{-3}$ (Sommer, 1986). For silicate, measured half saturation constants differ between natural Antarctic assemblage und cultures. For Antarctic diatoms in culture, Sommer (1986) recorded half saturation constants up to $89 \mathrm{mmol}$ $\mathrm{m}^{-3}$. In experiments during cruises in the Indian sector of the Southern Ocean, Jaques (1983) recorded a half saturation constant of $12 \mathrm{mmol} \mathrm{m}^{-3}$ for Antarctic diatoms. In a naturally occurring Antarctic diatom assemblage, Nelson and Tréguer (1992) recorded half saturation constants from 1.1 to 4.6 mmol m${ }^{-3}$. We decided to choose $k_{\mathrm{S}_{\mathrm{i}}}=4.6$. The effect of different values for $k_{\mathrm{S}_{\mathrm{i}}}$, however, is investigated in a series of sensitivity experiments.

Following Evans and Parslow (1985) and Fasham et al. (1990), the light dependent growth rate $\omega$ is described by

$\omega=\frac{1}{h} \int_{\Delta t} \int_{0}^{h} \frac{V_{\mathrm{P}} \alpha I(z, t)}{\sqrt{V_{\mathrm{P}}^{2}+\alpha^{2} I^{2}(z, t)}} \mathrm{e}^{-\left(k_{\mathrm{w}}+k_{\mathrm{c}} \mathrm{P}\right) z} \mathrm{~d} z \mathrm{~d} t$

where $h$ denotes the mixed layer depth and $I$ is the intensity of the photosynthetic active radiation (PAR) in a depth $z$ below the surface. For the conversion from solar radiation to PAR, we use a factor of $43 \%$ according to Jerlov (1976) and Jitts et al. (1976) and assume a surface albedo of 0.8. As the Southern Ocean belongs to oceanic type I (Jerlov, 1976; Bracher and Tilzer, 2000), we chose $k_{\mathrm{w}}=0.04 \mathrm{~m}^{-1}$ (Lorenzen, 1972) as the attenuation coefficient of sea water. The self-shading parameter $k_{\mathrm{c}}=0.07 \mathrm{~m}^{2}$ 
mmol $\mathrm{N}^{-1}$ and the initial slope $\alpha=0.027$ (W $\left.\mathrm{m}^{-2}\right)^{-1}$ day $^{-1}$ of the PI curve were taken from cruise measurements during the SO-JGOFS cruise ANT XIII/2 (Bracher et al., 1999). For the maximum growth rate $V_{\mathrm{P}}$, we took the maximum growth rate from Eppley (1972), which is 1.2 doublings day $^{-1}$ at maximum temperatures of about $6^{\circ} \mathrm{C}$ at $50^{\circ} \mathrm{S}$.

\subsubsection{Zooplankton}

Temporal changes of the zooplankton biomass are due to grazing, mortality, excretion and effects by entrainment and diffusion:

$$
\frac{\mathrm{d} Z}{\mathrm{~d} t}=\beta g_{\mathrm{Z}}-\mu_{\mathrm{Z}} \mathrm{Z}^{2}-\varepsilon \mathrm{Z}+D_{\mathrm{Z}}
$$

As we are mostly interested in the factors controlling the building up of phytoplankton blooms we only consider the herbivorous part of zooplankton. $\beta$ is the assimilation efficiency, so $\beta g_{\mathrm{Z}}$ gives the growth rate of zooplankton biomass while $(1-\beta) g_{Z}$ is the part of ingested food that is excreted as faecal pellets. The grazing rate $g_{Z}$ is derived from experiments with the abundant herbivorous copepod species Calanoides acutus (Schnack, 1985) and reads

$g_{\mathrm{Z}}=0.063(79.5 \mathrm{P})^{1.3} \frac{10^{-3}}{0.14 \cdot 86,400} \mathrm{Z}$

where the number 79.5 and the fraction $10^{-3} /[0.14$ $\cdot 86,400]$ result from the conversion from carbon $[\mu \mathrm{g}$ $\mathrm{l}^{-1}$ ] to nitrogen units [mmol $\mathrm{m}^{-3}$ ], assuming the average carbon content of an adult individuum of $C$. acutus to be $0.14 \mathrm{mg}$ (Schnack, 1985). Following Fasham (1995) and Steele and Henderson (1992), the mortality of zooplankton through higher predators is parameterized as a quadratic function. The natural mortality rate is quite low for adult copepods $(<0.01$ day $^{-1}$ according to Huntley et al., 1994 and Aksnes, 1996), therefore the greatest part of mortality is the loss to higher predators. Choosing $\mu_{\mathrm{Z}}=2 \mathrm{~m}^{3} \mathrm{mmol}$ $\mathrm{N}^{-1}$ day $^{-1}$ leads to a mortality of $10-18 \%$ per day for typically occurring zooplankton concentrations. The excretion rate of $20.2 \mathrm{ng} \mathrm{N} \mathrm{mg}{ }^{-1}$ dry wt. $\mathrm{h}^{-1}$
(Huntley and Nordhausen, 1995) has been converted to $\varepsilon=0.0078$ day $^{-1}$. $D_{\mathrm{Z}}$ denotes the mixing across the pycnocline and effects of changes in mixed layer depth.

\subsubsection{Nutrients}

Temporal changes of the concentrations of nutrients are due to uptake of phytoplankton, exudation, excretion and entrainment and diffusion. Although we do not allow ammonium supply to limit phytoplankton growth, the uptake ratio between ammonium and nitrate is determined using their concentration $\mathrm{N}_{\mathrm{a}}$ and $\mathrm{N}_{\mathrm{i}}$ and half saturation constants $k_{\mathrm{N}_{\mathrm{a}}}$ and $k_{\mathrm{N}_{\mathrm{i}}}$ :

$$
\frac{\mathrm{dN}_{\mathrm{i}}}{\mathrm{d} t}=-\sigma \frac{\frac{\mathrm{N}_{\mathrm{i}}}{k_{\mathrm{N}_{\mathrm{i}}}+\mathrm{N}_{\mathrm{i}}}}{\frac{\mathrm{N}_{\mathrm{i}}}{k_{\mathrm{N}_{\mathrm{i}}}+\mathrm{N}_{\mathrm{i}}}+\frac{\mathrm{N}_{\mathrm{a}}}{k_{\mathrm{N}_{\mathrm{a}}}+\mathrm{N}_{\mathrm{a}}}} \mathrm{P}+D_{\mathrm{N}_{\mathrm{i}}}
$$

$$
\begin{gathered}
\frac{\mathrm{dN}_{\mathrm{a}}}{\mathrm{d} t}=-\sigma \frac{\frac{\mathrm{N}_{\mathrm{a}}}{k_{\mathrm{N}_{\mathrm{a}}}+\mathrm{N}_{\mathrm{a}}}}{\frac{\mathrm{N}_{\mathrm{i}}}{k_{\mathrm{N}_{\mathrm{i}}}+\mathrm{N}_{\mathrm{i}}}+\frac{\mathrm{N}_{\mathrm{a}}}{k_{\mathrm{N}_{\mathrm{a}}}+\mathrm{N}_{\mathrm{a}}}} \mathrm{P} \\
+\gamma \sigma \mathrm{P}+\varepsilon \mathrm{Z}+D_{\mathrm{N}_{\mathrm{a}}}
\end{gathered}
$$

$\frac{D \mathrm{~S}_{\mathrm{i}}}{D t}=-\sigma r \mathrm{P}+D_{\mathrm{S}_{\mathrm{i}}}$

Following the observations in the Southern Ocean of Nelson and Smith (1986), Shiomoto and Ishii (1995) and Hense et al. (1998), we chose an Si:N uptake ratio $r=4$ for the reference simulation.

\subsubsection{Detritus}

In a couple of sensitivity experiments we investigate the influence of remineralization and silica dissolution on the development of plankton dynamics. For these experiments we add a detritus pool decomposed into a nitrogen part $\operatorname{Det}_{\mathrm{N}}$ and a silica part Det $_{\mathrm{S}_{i}}$. Temporal changes in both compartments are due to mortality of phyto- and zooplankton, produc- 
tion of faecal pellets, remineralization and effects of entrainment, diffusion and sinking:

$$
\begin{aligned}
\frac{\mathrm{dDet}_{\mathrm{N}}}{\mathrm{d} t}= & \mu_{\mathrm{P}} \mathrm{P}+\mu_{\mathrm{Z}} \mathrm{Z}+(1-\beta) g_{\mathrm{Z}} \\
& -\tau_{\mathrm{N}_{\mathrm{a}}} \operatorname{Det}_{\mathrm{N}}+D_{\operatorname{Det}_{\mathrm{N}}} \\
\frac{\mathrm{dDet}_{\mathrm{S}_{\mathrm{i}}}}{\mathrm{d} t}= & \left(\mu_{\mathrm{P}} \mathrm{P}+\mu_{\mathrm{Z}} \mathrm{Z}+g_{\mathrm{Z}}\right) r-\tau_{\mathrm{S}_{\mathrm{i}}} \operatorname{Det}_{\mathrm{S}_{\mathrm{i}}}+D_{\operatorname{Det}_{\mathrm{S}_{\mathrm{i}}}}
\end{aligned}
$$

Using the term $(1-\beta) g_{\mathrm{Z}}$, we assume that faecal pellet production is proportional to zooplankton grazing. As silica is not stored in zooplankton biomass, the whole ingested silica part of phytoplankton is led to the silica part of the detritus pool. The detritus losses through remineralization or dissolution are described as $\tau_{\mathrm{N}_{\mathrm{a}}}$ Det $_{\mathrm{N}}$ and $\tau_{\mathrm{S}_{\mathrm{i}}}$ Det $_{\mathrm{S}_{\mathrm{i}}}$, respectively, and form additional sources of silicate and ammonium. Time constants of mineralization to ammonium and silica dissolution were derived from observations of Biddanda (1988) and measurement of Tréguer et al. (1989). Their values are $\tau_{\mathrm{N}_{\mathrm{a}}}=0.07 \mathrm{day}^{-1}$ and $\tau_{\mathrm{S}_{\mathrm{i}}}=$ 0.018 day $^{-1}$ (at $6^{\circ} \mathrm{C}$ ).

\subsubsection{Entrainment and diffusion}

Cross-pycnocline mixing and entrainment are computed using the Fickian diffusion approach and assuming a linear profile between the mixed layer base $(z=-h)$ and an arbitrary reference depth $(z=$ $\left.-h_{\mathrm{b}}\right)$. The resulting fluxes for any tracer concentration $T$ within the mixed layer are

$D_{\mathrm{T}}=\frac{1}{h}\left(a_{\mathrm{v}} \frac{T_{\mathrm{b}}-T}{h_{\mathrm{b}}-h}+w_{\mathrm{ent}}\left(T_{\mathrm{ent}}-T\right)\right)$,

where the subscript $\mathrm{b}$ denotes the respective concentration at $z=-h_{\mathrm{b}}$ and variables without subscript denote properties of the mixed layer. We chose $a_{\mathrm{v}}=10^{-3} \mathrm{~m}^{2} \mathrm{~s}^{-1}$ as the vertical diffusion coefficient; $w_{\text {ent }}$ represents the entrainment velocity. In contrast to Fasham et al. (1990), no discontinuity in tracer concentrations at the nutricline is assumed. Closer to observed nutrient profiles in the region of the Antarctic Polar Front (Löscher et al., 1997), we assume a linear profile between $z=-h$ and $z=$ $-h_{\mathrm{b}}$. From that, we estimate the tracer concentration involved in the entrainment flux to be

$T_{\text {ent }}=T+\frac{T_{\mathrm{b}}-T}{h_{\mathrm{b}}-h} \delta h$

where $\delta h$ represents the thickness of an entrainment zone assumed to be $8 \mathrm{~m}$ (Lemke et al., 1990).

Except for zooplankton, concentrations within the mixed layer are modified only in case of entrainment, but not for mixed layer retreat. Zooplankton, however, is able to actively stay in the mixed layer, so that its concentration increases in case the mixed layer gets shallower. For this reason, as in Fasham et al. (1990), the entrainment velocity used in Eqs. (11) and (12) is restricted to positive values for all compartments except for zooplankton.

For detritus, an additional term accounting for sinking with a velocity $V$

$D_{\mathrm{V}}=-V \frac{\text { Det }}{h}$

is applied to both $\operatorname{Det}_{\mathrm{N}}$ and $\operatorname{Det}_{\mathrm{S}_{\mathrm{i}}}$.

\subsection{Initialization and forcing}

Model runs are initialized with winter values in all compartments. For phytoplankton, we chose of $0.2 \mu \mathrm{g}$ Chl $a / 1$, and for zooplankton $0.1 \mu \mathrm{g} \mathrm{C} / 1$. Following the WOCE data set, initial nutrient concentrations are $26 \mu \mathrm{mol} / 1$ for nitrate, $0.2 \mu \mathrm{mol} / 1$ for ammonium and $14 \mu \mathrm{mol} / 1$ for silicate.

Nutrient data from the WOCE data set are also used as the lower boundary, which was chosen to be at $h_{\mathrm{b}}=300 \mathrm{~m}$. Phyto- and zooplankton and detritus concentrations at $z=-h_{\mathrm{b}}$ are assumed to be zero. For zooplankton this might not be quite correct, but we only consider herbivorous zooplankton and these concentrate in the mixed layer (in the upper $100 \mathrm{~m}$ depth according to Fransz and Gonzalez, 1997).

The model is forced by annual cycles of the mixed layer depth and solar radiation. Mixed layer depth is derived from model runs with a mesoscale application of the $s$-Coordinate Primitive Equation Model SPEM (Haidvogel et al., 1991; modified by Song and Haidvogel, 1994 and Beckmann et al., 1999). For the solar radiation, the daily and annual cycles, latitude and mean cloud cover, using the 
Table 1

Parameter values for reference experiment

\begin{tabular}{lll}
\hline Parameter & Symbol & Value \\
\hline For phytoplankton & & $0.027 \mathrm{~m}^{2} \mathrm{~W}^{-1} \cdot \mathrm{day}^{-1}$ \\
Initial slope of the PI curve & $\alpha$ & $1.2 \mathrm{day}^{-1}$ \\
Maximum growth rate & $\sigma$ & $0.5 \mathrm{day}^{-1}$ \\
Mortality rate & $\mu_{\mathrm{P}}$ & $4.6 \mathrm{mmol} \mathrm{m}^{-3}$ \\
Half saturation constant for silicate & $k_{\mathrm{S}_{\mathrm{i}}}$ & $0.3 \mathrm{mmol} \mathrm{m}^{-3}$ \\
Half saturation constant for nitrate & $k_{\mathrm{N}_{\mathrm{a}}}$ & $0.3 \mathrm{mmol} \mathrm{m}^{-3}$ \\
Half saturation constant for ammonium & $\gamma$ & $5 \%$ \\
Exudation fraction & & \\
& & \\
For zooplankton & $\beta$ & $0.67 \%$ \\
Assimilation efficiency & $\varepsilon$ & $2.0078 \mathrm{day}^{-1} \mathrm{mmol}^{-1} \cdot \mathrm{day}^{-1}$ \\
Excretion rate & $\mu_{\mathrm{Z}}$ & \\
Mortality rate & & 4 \\
For nutrients & & \\
Si:N ratio in the standard model runs & $r$ & $0.018 \mathrm{day}^{-1}$ \\
For detritus (for sensitivity model runs) & & $0.07 \mathrm{day}^{-1}$ \\
Silica dissolution rate & $\tau_{\mathrm{S}_{\mathrm{i}}}$ & $1,5,10 \mathrm{~m} \mathrm{day}^{-1}$ \\
Remineralization rate & $\tau_{\mathrm{N}_{\mathrm{a}}}$ & \\
Sinking rate & $V$ &
\end{tabular}

standard astronomical formulae of Zillmann (1981) and Laevastu (1960), are considered. The cloud cover was chosen to be $80 \%$, in agreement with the reanalysis data of the ECMWF. A daily time step is applied. The parameter values for the reference experiment are given in Table 1 .

\section{Results}

\subsection{The reference simulation}

The reference simulation features a pronounced seasonal cycle of plankton and nutrients (Fig. 1) with concentrations in good agreement with observations. In October, when the solar radiation increases and the mixed layer retreats, phytoplankton growth begins (Fig. 1a). Phytoplankton biomass reaches its maximum in January with concentrations of up to 3 $\mu \mathrm{g} \mathrm{Chl} a 1^{-1}$ when the mixed layer is shallowest $(\leq 20 \mathrm{~m})$. Typical summer concentrations of phytoplankton measured in that region are in the range from 2 to $4.5 \mu \mathrm{g} \mathrm{Chl} a 1^{-1}$ (Lutjeharms et al., 1985; Dafner and Mordasova, 1994; Bathmann et al., 1997). Zooplankton starts to develop in November shortly after the onset of phytoplankton growth and reaches its maximum between November and February with maximum concentrations of $7 \mu \mathrm{g} \mathrm{C}^{-1}$ (Fig. 1b). Observed maximum zooplankton biomass in summer is in the range from 8 to $16 \mathrm{mg}$ ash free dry weight (AFDW) $\mathrm{m}^{-3}$ (Fransz and Gonzalez, 1997). Assuming that $1 \mathrm{mg}$ AFDW m ${ }^{-3}$ comprises $0.46 \mathrm{mg} \mathrm{C}$ $\mathrm{m}^{-3}$ (Paffenhoefer and Harris, 1976), these observed zooplankton concentrations are in the range of 3.68$7.36 \mu \mathrm{g} \mathrm{C}^{-1}$. Simulated summer zooplankton concentrations are therefore in good agreement with measurements.

While nitrate concentration remains high, silicate is depleted from November onwards (Fig. 1c), leading to a nutrient limitation which is visible in the increasing difference between light limited and actual growth rate (Fig. 1d). Simulated silicate and nitrate concentrations are in the range of observations with concentrations $<1 \mu \mathrm{mol}^{-1}$ in summer (Quéguiner et al., 1997) for silicate and about 22 $\mu$ mol $1^{-1}$ for nitrate (Löscher et al., 1997; Hartmann et al., 1997). The absence of a strong decrease in nitrate concentration in summer is a prominent feature of the ecosystem near the Antarctic Polar Front and has been repeatedly observed (Löscher et al., 1997; Hartmann et al., 1997; Dafner and Mordasova, 1994) and is also a distinctive feature of model 
phytoplankton

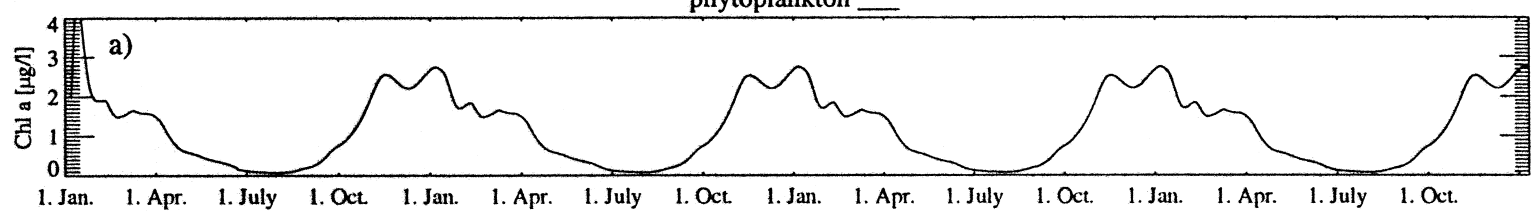

zooplankton

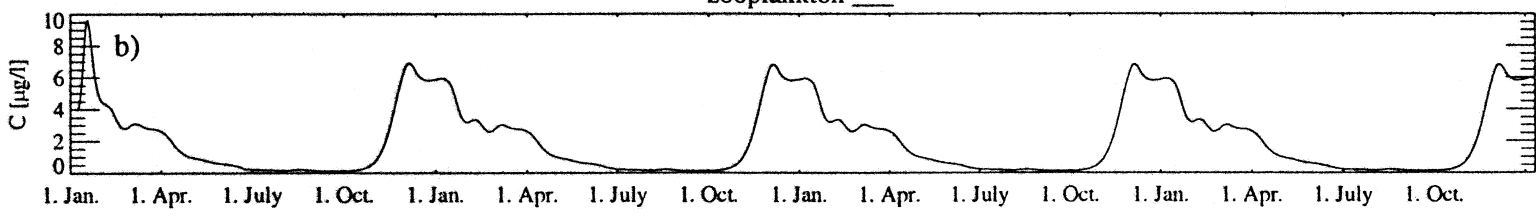

silicate __ nitrate .....

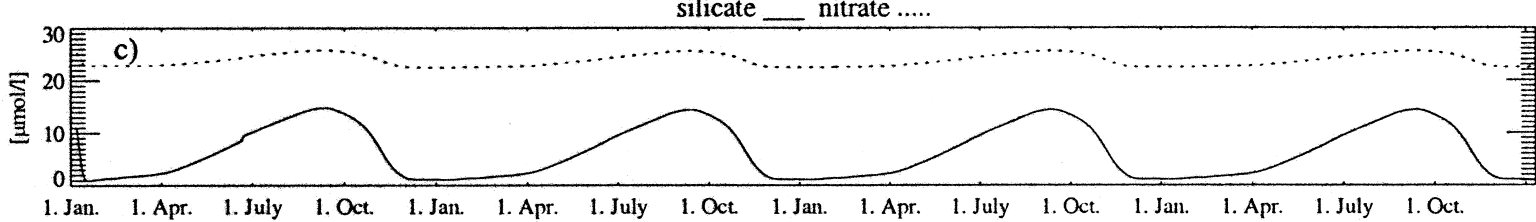

light limited growth rate _ and actual growth rate ...

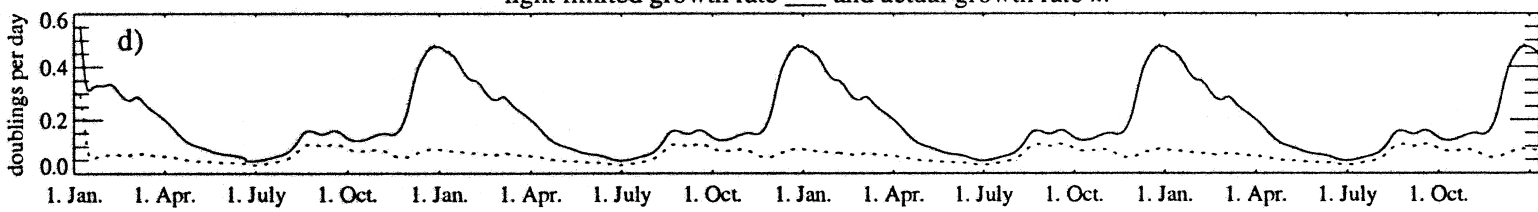

primary production

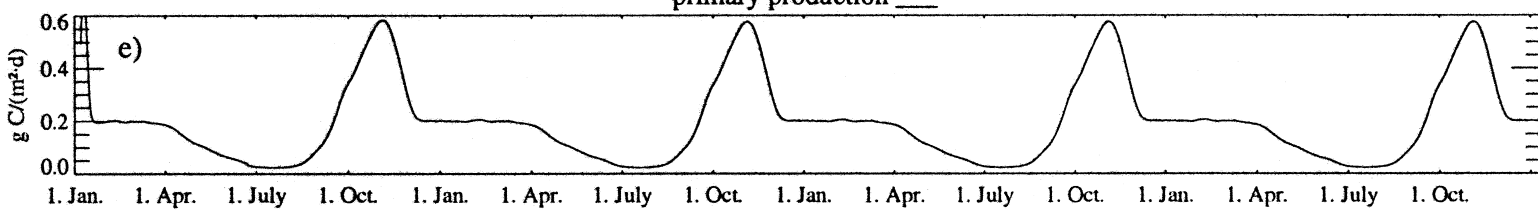

mixed layer depth

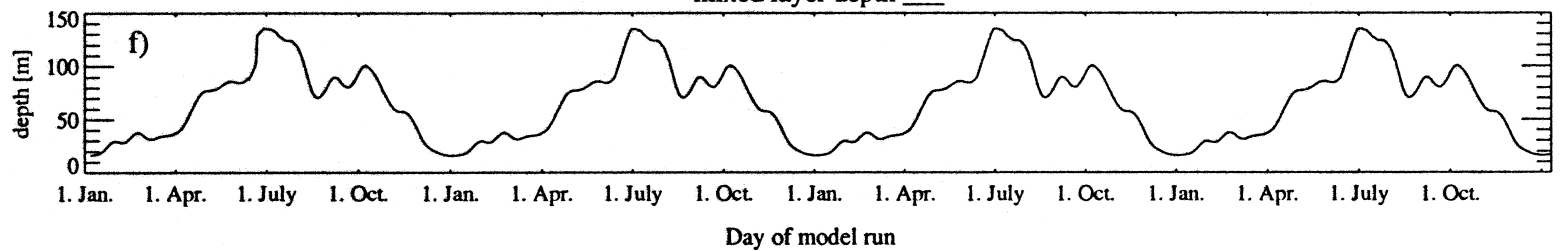

Fig. 1. Simulated concentrations of (a) phytoplankton, (b) zooplankton, (c) silicate and nitrate, (d) light-limited growth rate and actual growth rate, (e) vertically integrated daily primary production and (f) mixed layer depth in the reference experiment.

studies in the Southern Ocean (e.g., Pondaven et al., 1999; Lancelot et al., 2000).

Maximum daily primary production is $0.6 \mathrm{~g} \mathrm{C}$ $\mathrm{m}^{-2}$ or about $30 \mathrm{mmol}$ silicate $\mathrm{m}^{-2}$ in November (Fig. 1e) and therefore, agrees well with observations ranging from 0.3 to $1.2 \mathrm{~g} \mathrm{C} \mathrm{m}^{-2}$ (Dafner and Mordasova, 1994; Quéguiner et al., 1997; Bracher et al., 1999).

From February onwards, an increasing mixed layer depth (Fig. 1f) leads to entrainment of further nutri- 
ents and therefore allows for further growth of phytoplankton. However, the decline of the solar radiation and further deepening of the mixed layer lead to a decrease of phytoplankton biomass. In April, phytoplankton concentration has gone down below $1 \mu \mathrm{g}$ Chl $a 1^{-1}$ and zooplankton has decreased to concentrations lower than $1 \mu \mathrm{g} \mathrm{C} 1^{-1}$.

During the winter, nutrients are replenished due to further entrainment and cross-pycnocline mixing. Maximum concentrations of $15 \mu \mathrm{mol} 1^{-1}$ for silicate and $26 \mu \mathrm{mol} 1^{-1}$ for nitrate occur just before the phytoplankton starts to develop. Winter concentrations of silicate and nitrate compare well with measurements during Polarstern cruise ANT X/4 (Lemke et al., 1992).

Time series of the nitrogen fluxes between the different compartments (Fig. 2a,b) indicate that phytoplankton growth is predominantly balanced by phytoplankton mortality while zooplankton grazing appears to play a minor role. Similar to that, zooplankton growth is balanced by mortality (including feeding pressure by higher predators) while excretion is negligible.

Simulated ammonium concentrations (not shown) are maximum $\left(0.1 \mu \mathrm{mol} \mathrm{l}^{-1}\right)$ and therefore significantly lower than observed ammonium concentrations ( 0.2 to $0.4 \mu \mathrm{mol} 1^{-1}$ in the mixed layer; Tréguer and Jacques, 1992).

Thus, our reference experiment gives thoroughly reasonable results, however ammonium concentration is underestimated.

\subsection{Experiments with remineralization and dissolu- tion of silica}

To investigate the effect of remineralization and dissolution of silica, a couple of sensitivity experiments with different sinking velocities has been performed. All experiments (Fig. 3) show only minor differences from the reference simulation.

The effect of remineralization and dissolution of silica is most obvious in the experiment with a low sinking rate of $1 \mathrm{~m} \mathrm{day}^{-1}$ : Compared to simulations with higher sinking velocity, a longer residence time in the mixed layer leads to higher concentrations of biogenic silica (which comprises the silica part of detritus as well as of phytoplankton cells) and thus to a more pronounced contribution of silica dissolution. Due to the higher silicate concentrations in summer, primary production is increased and higher phytoand zooplankton biomasses are produced (Fig. 3a-d).

The maximum simulated BSi concentrations of 15 $\mu \mathrm{mol}^{-1}$ for a sinking rate of $1 \mathrm{~m} \mathrm{day}^{-1}$ and 10 and $7 \mu \mathrm{mol} \mathrm{l}^{-1}$ for a sinking rate of 5 and $10 \mathrm{~m} \mathrm{day}^{-1}$ (Fig. 3e) are quite comparable with results from a more complex plankton model comprising 29 state variables (Lancelot et al., 2000) and with observed BSi concentrations between 2.76 and $11.7 \mu \mathrm{mol} 1^{-1}$ (Quéguiner et al., 1997).

The simulated maximum POC concentrations are in the range of $150-250 \mu \mathrm{g}^{-1}$ for a sinking rate of 1,5 and $10 \mathrm{~m} \mathrm{day}^{-1}$ (Fig. 3f) - which are in the range of observations (Bathmann et al., 1997). Am-
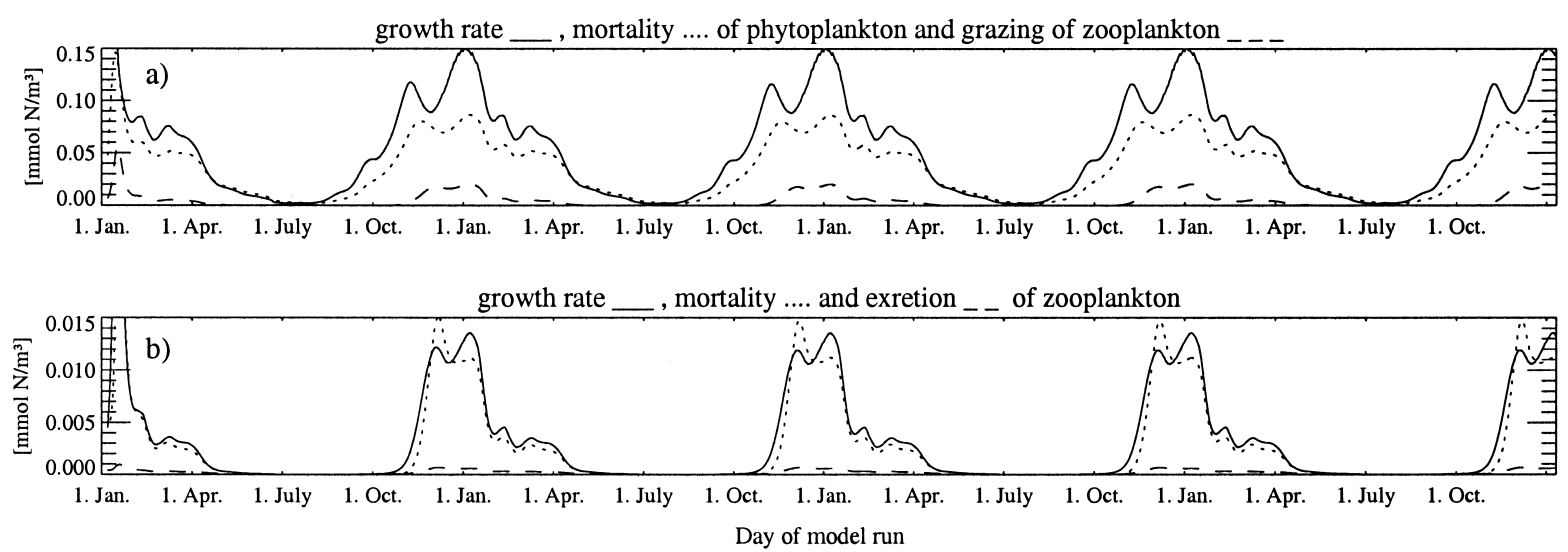

Fig. 2. Nitrogen fluxes for the compartments (a) phyto- and b) zooplankton. Displayed are (a) phytoplankton growth (solid) and mortality (dotted), and zooplankton grazing (dashed), and (b) zooplankton growth (solid), mortality (dotted) and excretion (dashed). Note the different scales. 
phytoplankton
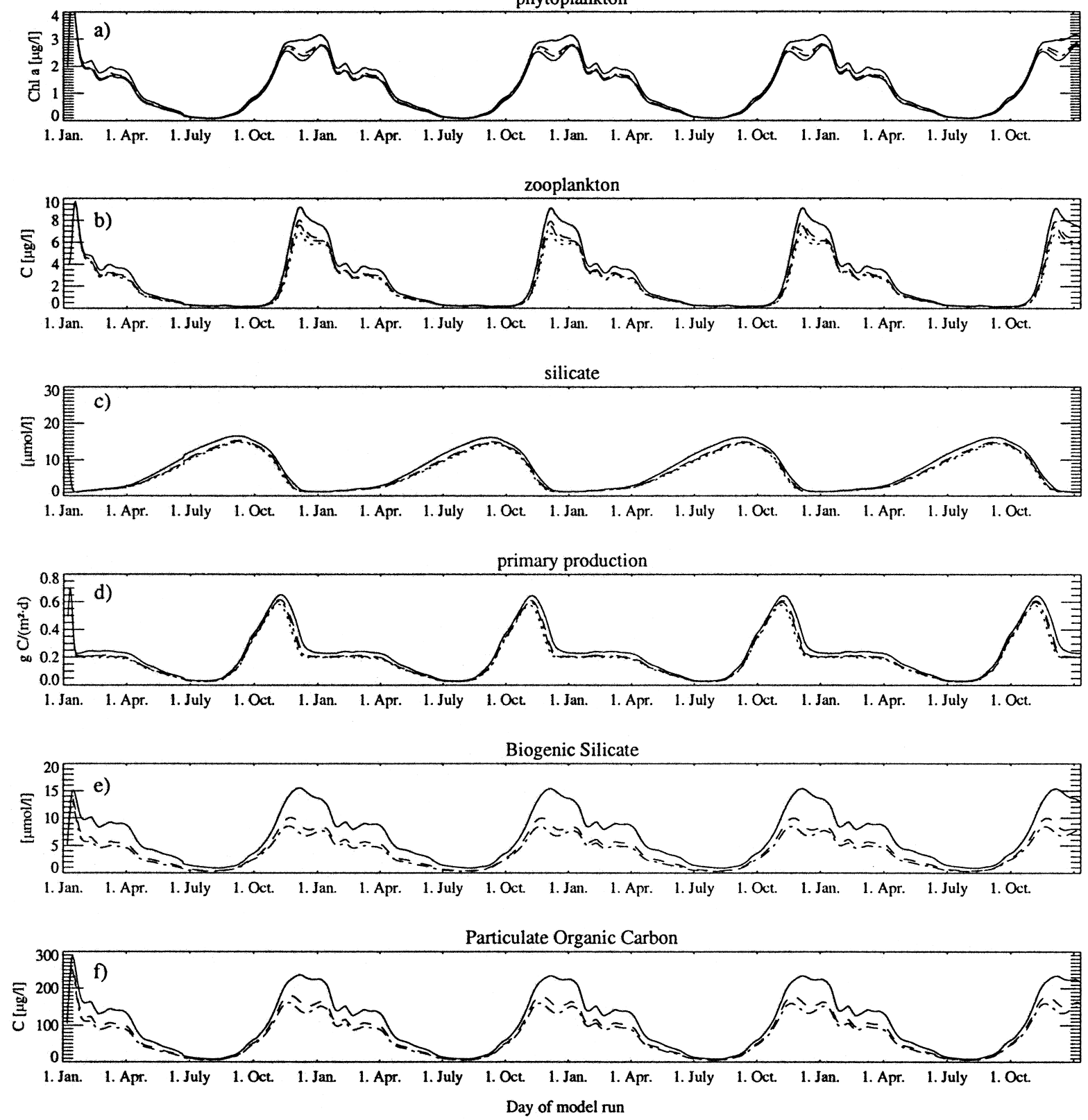

Fig. 3. Simulated concentrations of (a) phytoplankton, (b) zooplankton, (c) silicate and (d) vertically integrated primary production in the reference simulation (dotted) and experiments with remineralization and dissolution of silica using different sinking velocities of $1 \mathrm{~m}$ day ${ }^{-1}$ (solid), $5 \mathrm{~m} \mathrm{day}^{-1}$ (dashed) and $10 \mathrm{~m} \mathrm{day}^{-1}$ (dashed-dotted).

monium concentrations (not shown) are more realistic than in the reference simulation with concentrations between 0.4 and $0.5 \mu \mathrm{mol} 1^{-1}$ for sinking rates of 5 and $10 \mathrm{~m} \mathrm{day}^{-1}$, respectively, but overestimated with concentrations of up to $1.3 \mu \mathrm{mol} 1^{-1}$ in the experiment with $V=1 \mathrm{~m}^{-1}{ }^{-1}$.

We conclude that disregarding dissolution and remineralization leads to an underestimation of am- 
monium concentration but has no significant effect on the development and the amount of plankton biomasses.

\subsection{Experiments with different half saturation con- stants of silicate}

Laboratory experiments with different diatom species gave silicate half saturation constants of 4.2 mmol m $\mathrm{m}^{-3}$ for $T$. antarctica, $34.5 \mathrm{mmol} \mathrm{m}^{-3}$ for $C$. criophilum and $88.7 \mathrm{mmol} \mathrm{m}^{-3}$ for $F$. kerguelensis (Sommer, 1986, 1991). For a natural diatom commu- nity Nelson and Tréguer (1992) recorded half saturation constants of 1.1-4.6 $\mathrm{mmol} \mathrm{m}^{-3}$.

For the reference simulation, we chose $k_{\mathrm{S}_{\mathrm{i}}}=4.6$ $\mathrm{mmol} \mathrm{m} \mathrm{m}^{-3}$. In order to investigate the sensitivity to different half saturation constants we performed a couple of experiments with $k_{\mathrm{S}_{\mathrm{i}}}=1.1,8$ and 34.5 mmol $\mathrm{m}^{-3}$.

It turns out that the experiment $k_{\mathrm{S}_{\mathrm{i}}}=8 \mathrm{mmol}$ $\mathrm{m}^{-3}$ reveals an annual cycle of plankton growth and decay, which is quite similar to the reference simulation (Fig. 4a,b). However, concentrations of dissolved silicate are slightly higher both in summer and in winter (Fig. 4c).
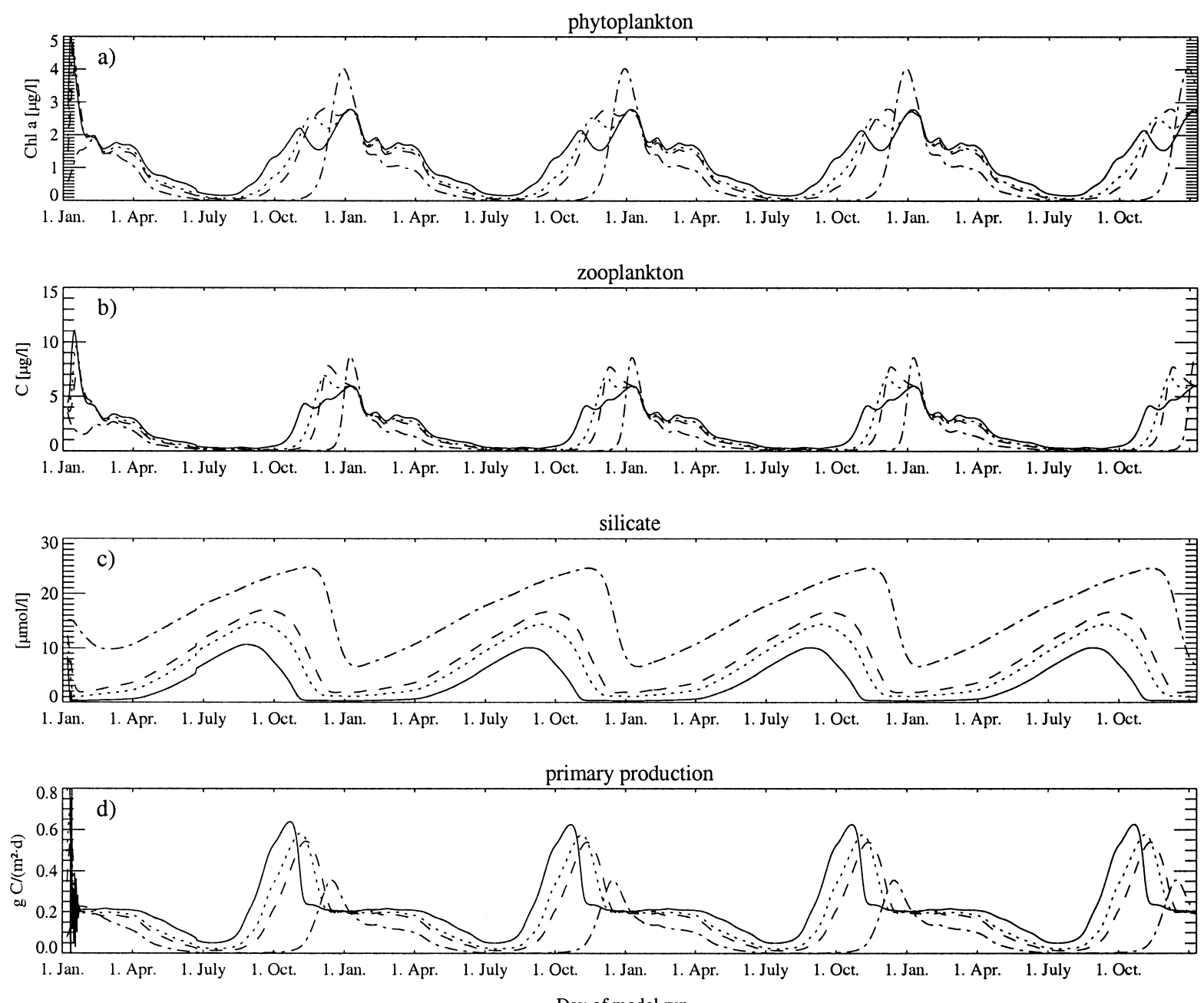

Day of model run

Fig. 4. Simulated concentrations of (a) phytoplankton, (b) zooplankton, (c) silicate and (d) vertically integrated primary production in the reference simulation (dotted) and experiments with half saturation constants $k_{\mathrm{S}_{\mathrm{i}}}$ of 1.1 (solid), 8 (dashed) and 34.5 (dashed-dotted). 
In contrast to that, reducing the silicate half saturation constant to $1.1 \mathrm{mmol} \mathrm{m}^{-3}$ (Fig. 4, solid line) leads to slightly lower concentrations of phyto- and zooplankton in November compared to the reference simulation (Fig. 4, dotted line). Primary production starts earlier but also ends up earlier due to a strong silicate depletion (Fig. 4d). While maximum silicate concentrations are only $10 \mathrm{mmol} \mathrm{m}^{-3}$, silicate is totally depleted with concentrations near $0 \mathrm{mmol}$ $\mathrm{m}^{-3}$ for almost 5 months.

In contrast to that, a half saturation constant of $34.5 \mathrm{mmol} \mathrm{m}^{-3}$ (Fig. 4, broken line) eliminates the depletion of silicate; silicate remains high with minimum concentrations of $6 \mathrm{mmol} \mathrm{m}^{-3}$. In this experiment, the onset of phytoplankton growth is delayed by roughly 2 months. Due to the reduced growth rates, no silicate depletion occurs; hence the maximum phyto- and zooplankton concentrations are even higher than in the reference simulation. However, the bloom is much shorter so that integrated daily primary production is quite low with maximum values of $0.3 \mathrm{~g} \mathrm{C} \mathrm{m}^{-2}$.

From the annual cycles of nutrient concentrations, which show an unrealistic depletion for a long period
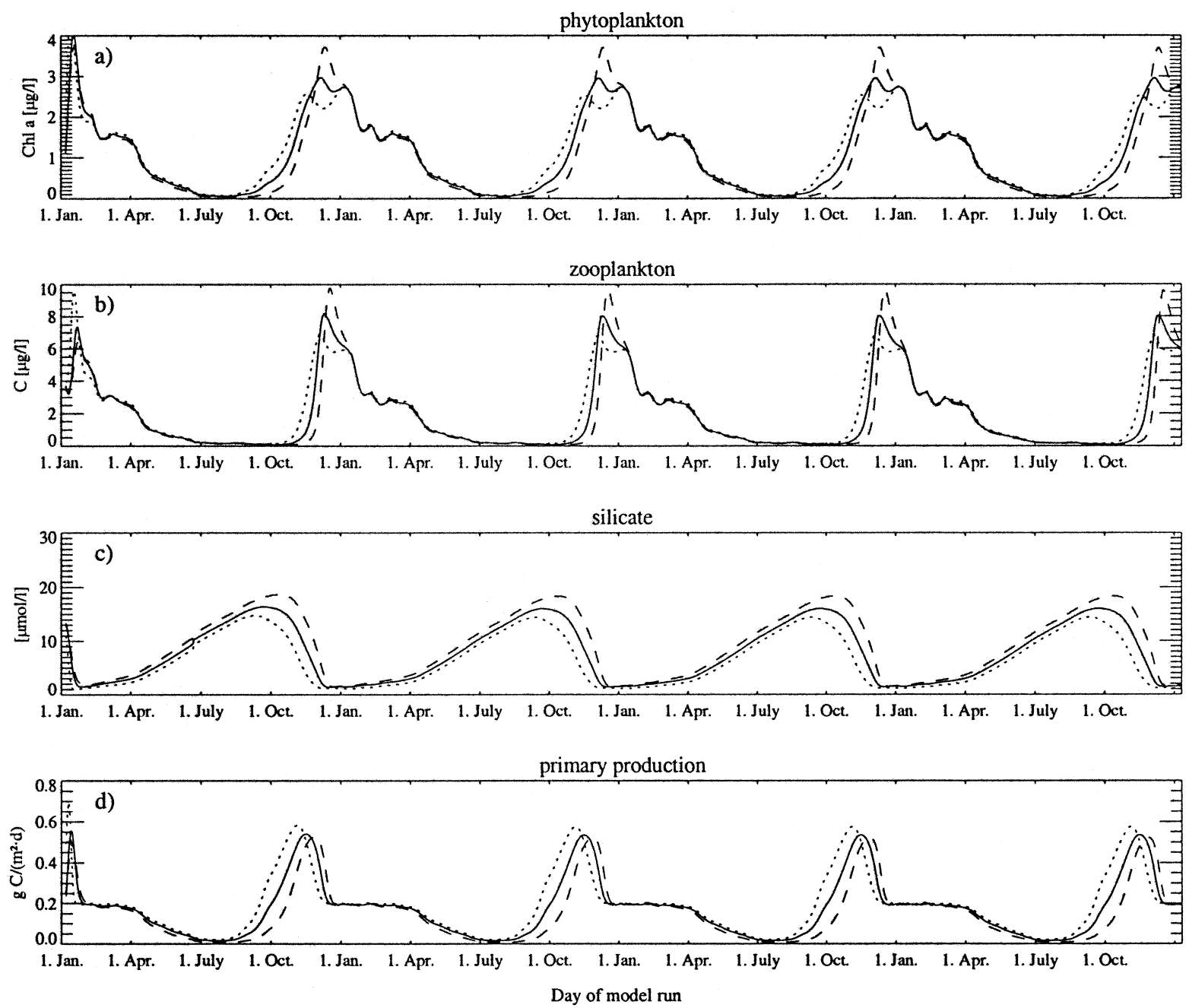

Fig. 5. Simulated concentrations of (a) phytoplankton, (b) zooplankton, (c) silicate and (d) vertically integrated primary production in the reference simulation (dotted) and experiments with reduced maximum growth rate (solid) and reduced actual growth rate (dashed). 
in case of $k_{\mathrm{S}_{\mathrm{i}}}=1.1 \mathrm{mmol} \mathrm{m}^{-3}$ or (equally unrealistic) no depletion at all in case of $k_{\mathrm{S}_{\mathrm{i}}}=34.5 \mathrm{mmol}$ $\mathrm{m}^{-3}$, we conclude that these half saturation constants are not typical for a natural diatom community at the Antarctic Polar Front.

\subsection{The role of iron}

As already mentioned, field and laboratory experiments have shown that iron addition enhances phytoplankton growth or vice versa iron deficiency could slow down primary production (e.g., Martin and Fitzwater, 1988). In addition to that, Hutchins and
Bruland (1998) as well as Takeda (1998) recorded higher Si:N uptake ratios in case of iron deficiency. As measurements of half saturation constants or equally suited criteria of the iron's impact on phytoplankton growth are not available for the Southern Ocean, the effect of iron limitation is tested by a couple of model experiments with reduced growth rates and different $\mathrm{Si}: \mathrm{N}$ uptake ratios.

\subsubsection{Reduced growth rates}

As iron-enrichment experiments show that the phytoplankton growth rate is reduced by maximum $30 \%$ due to iron deficiency (e.g., Takeda, 1998),
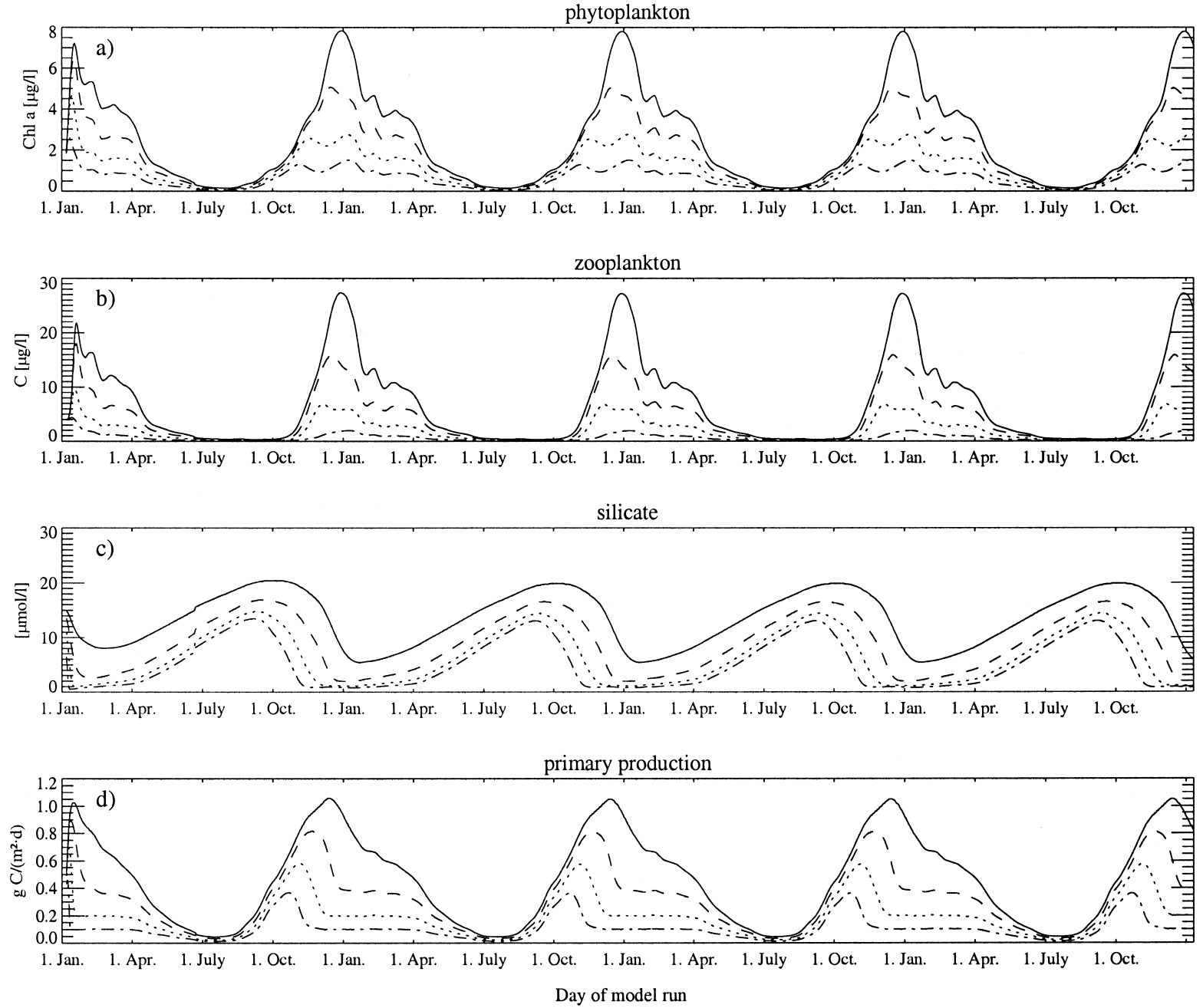

Fig. 6. Simulated concentrations of (a) phytoplankton, (b) zooplankton, (c) silicate and (d) vertically integrated primary production in the reference simulation (dotted) and experiments with an Si:N ratio of 1 (solid), Si:N of 2 (dashed) and Si:N of 8 (dashed-dotted). 
model runs with either the maximum growth rate or the actual growth rate reduced by $30 \%$ were carried out (Fig. 5).
A reduced maximum growth rate $(\omega=0.8$ instead of 1.2) has no significant effect on phyto- and zooplankton biomass (Fig. 5a,b). However, phytoplank-
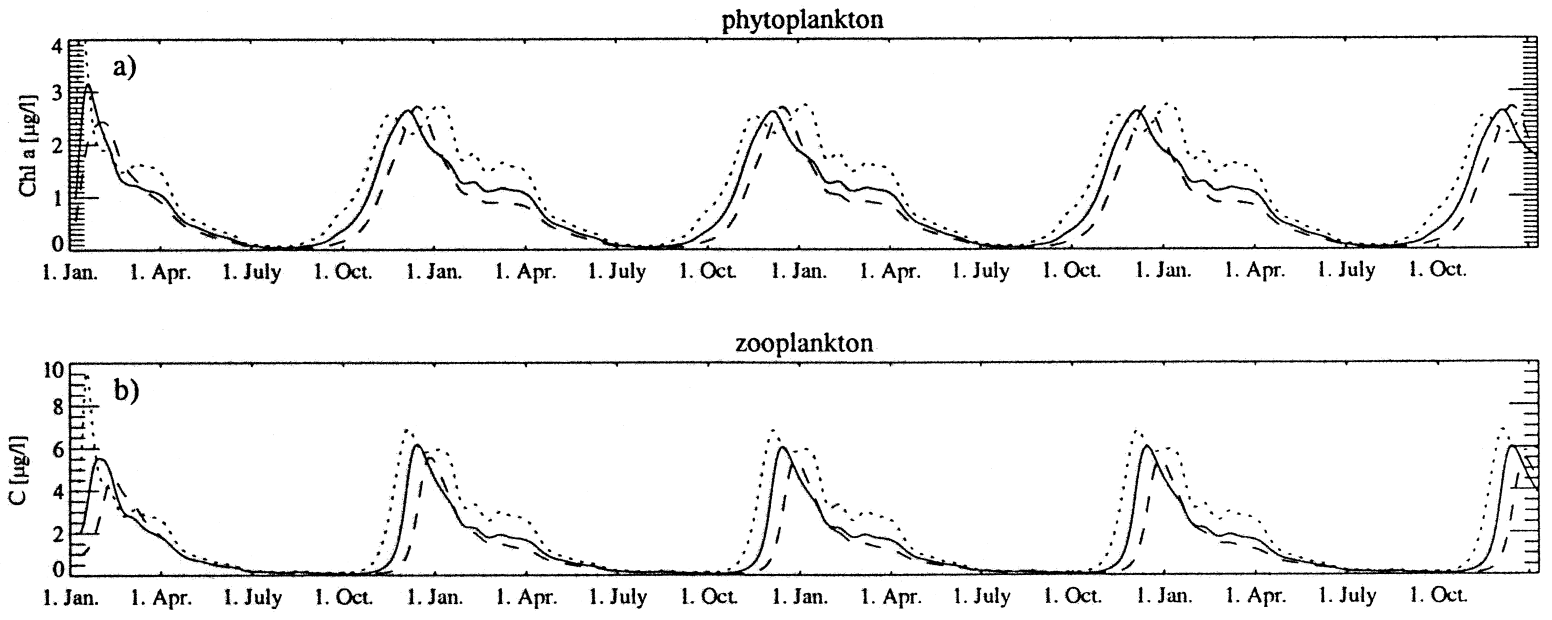

silicate

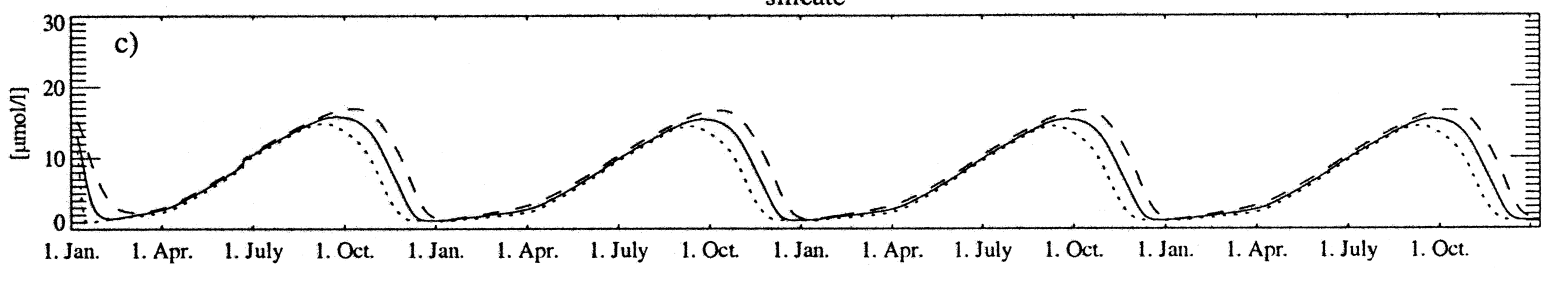

primary production

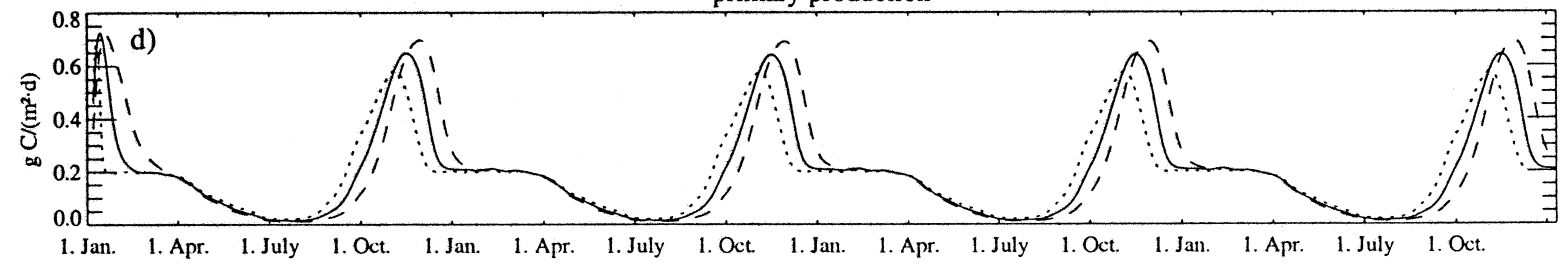

mixed layer depth

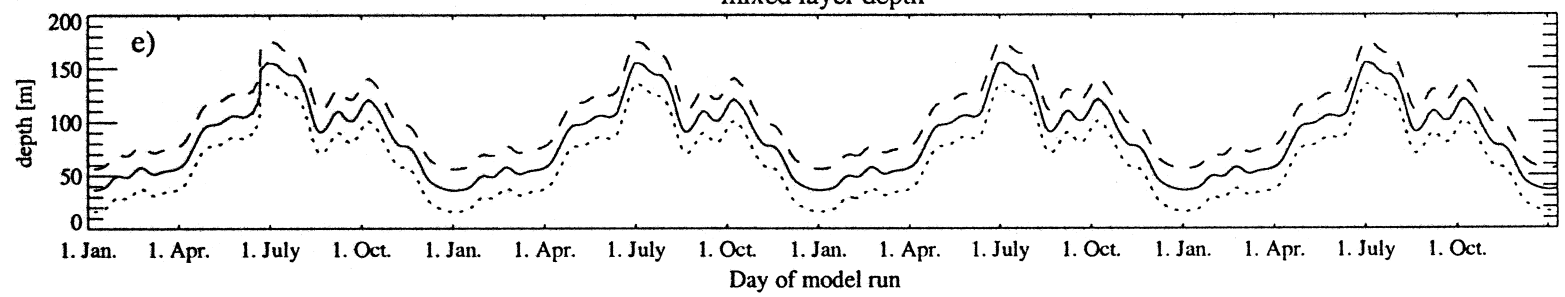

Fig. 7. Simulated concentrations of (a) phytoplankton, (b) zooplankton, (c) silicate, (d) vertically integrated primary production and (e) the mixed layer depth in the reference simulation (dotted) and experiments with changing the offset of the mixed layer depth of $20 \mathrm{~m}$ (solid) and $40 \mathrm{~m}$ (dashed). 
ton growth starts a little later and silicate is not as strongly depleted as in the reference simulation (Fig. 5c).

Reducing the actual growth rate by $30 \%$ leads to a higher phyto- and zooplankton biomass in January. The onset of the phytoplankton bloom is delayed by roughly 2 weeks and therefore, the maximum of primary production occurs later than in the reference simulation. Maximum primary production, however, is not significantly affected (Fig. 5d).

\subsubsection{Different Si:N uptake ratios}

Different $\mathrm{Si}: \mathrm{N}$ uptake ratios lead to pronounced variations in plankton biomasses (Fig. 6). Assuming a silicate to nitrate uptake ratio $r=1$ (solid line) instead of 4 (dotted) the simulation features a stronger seasonal cycle of both phyto- and zooplankton and nutrients (Fig. 6a-c). Maximum phytoplankton and zooplankton concentrations in this experiment are 8 $\mu \mathrm{g} \mathrm{Chl} a 1^{-1}$ and $30 \mu \mathrm{g} \mathrm{C}^{-1}$, respectively. While the high simulated integrated primary production of about $1.2 \mathrm{~g} \mathrm{C} \mathrm{m}^{-2} \mathrm{day}^{-1}$ (Fig. 6d) agrees with the observations of Quéguiner et al. (1997), phyto- or zooplankton concentrations that high have never been recorded in the region of the Antarctic Polar Front.

Looking at the other extreme end, an Si:N uptake ratio of 8 leads to a maximum phytoplankton concentration of only $1.5 \mu \mathrm{g} \mathrm{Chl} a 1^{-1}$ and a maximum zooplankton concentration of $2 \mu \mathrm{g} \mathrm{C} 1^{-1}$. Silicate depletion starts early in spring thus slowing down phytoplankton growth for the rest of the summer season. As a consequence, daily integrated primary production is strongly reduced with maximum values of $0.3 \mathrm{~g} \mathrm{C} \mathrm{m}^{-2}$ day $^{-1}$. Apparently, with increasing $\mathrm{Si}: \mathrm{N}$ uptake ratio, limitation of silicate becomes more and more important and as a consequence thereof, primary production and phyto- and zooplankton biomass decrease.

\subsection{The influence of mixed layer dynamics}

To study the impact of mixed layer dynamics on the development of a phytoplankton bloom, two experiments were performed with the mixed layer depth constantly increased by 20 and $40 \mathrm{~m}$, respectively (Fig. 7). In both experiments, phyto- and zooplankton show slightly lower biomasses in Jan- uary. Apart from that, the effect on the biomasses of phyto- and zooplankton is rather small.

\section{Discussion}

We have demonstrated that the zero-dimensional version of BIMAP gives a reasonable simulation of the annual cycle of plankton growth and decay in the Antarctic Polar Front. Maximum phyto- and zooplankton concentrations as well as the annual cycle of nutrient depletion and replenishment are realistically reproduced. Vertically integrated daily primary production agrees well with calculations based on measurements. Thus, the assumption of an Si:N uptake ratio of 4 appears to be justified. Although zero-dimensional, the model appears to capture essential aspects of hydrography through the annual cycle of mixed layer depth and the effects of diffusion and entrainment. However, ammonium concentrations are underestimated both during the bloom season and in the winter.

Model experiments including two compartments for the nitrogen- and the silica-fraction of detritus indicate that dissolution of silica only plays a minor role for nutrient supply in the mixed layer. While Nelson et al. (1995) estimated that globally $50 \%$ of the produced biogenic silica dissolves in the upper $100 \mathrm{~m}$ depth, they also pointed out that there are significant regional differences. According to Nelson and Gordon (1982), the Antarctic Circumpolar Current belongs to the region with the lowest silica dissolution rates in surface water which is consistent with the recorded high opal sedimentation in this region (DeMaster et al., 1991). There is some discussion going on about factors accelerating silica dissolution (e.g., Nelson et al., 1995; Bidle and Azam, 1999). However, considering effects like eddy pumping and the strong vertical movements associated with a meandering front, it is reasonable to conclude that in frontal regions remineralization might only play a minor role in nutrient supply.

Experiments with different values for the half saturation constant $k_{\mathrm{S}_{\mathrm{i}}}$ for silica uptake feature a surprisingly low sensitivity for a moderate range of values. While the experiments with $k_{\mathrm{S}_{\mathrm{i}}}=1.1,4.6$ and $8 \mathrm{mmol} \mathrm{m}^{-3}$ all reproduce silicate depletion in summer (probably exaggerated in case of $k_{\mathrm{S}_{\mathrm{i}}}=1.1$ 
mmol $\mathrm{m}^{-3}$ ), summer silicate concentrations are overestimated in the experiment with $k_{\mathrm{S}_{\mathrm{i}}}=34.5$ mmol m${ }^{-3}$. Pondaven et al. (1998) simulated silicate limitation at the KERFIX station assuming a half saturation constants of $8 \mathrm{mmol} \mathrm{m} \mathrm{m}^{-3}$ and pointed out that simulations with lower half saturation constants underestimate the summer silicate concentrations. However, in the region of the Antarctic Polar Front silicate depletion with minimum values of $2 \mathrm{mmol}$ $\mathrm{m}^{-3}$ and lower was frequently reported (Dafner and Mordasova, 1994; Quéguiner et al., 1997; Hartmann et al., 1997) which leads us to conclude that half saturation constants for silica uptake in the range from 4 to $8 \mathrm{mmol} \mathrm{m}^{-3}$ are suitable for a realistic simulation of the plankton community in the region of the Antarctic Polar Front.

The possible effects of iron limitation were investigated in a couple of experiments with different $\mathrm{Si}$ N uptake ratios or reduced maximum or actual growth rates. It turns out that primary production as well as phyto- and zooplankton biomass are affected more by variations of the $\mathrm{Si}: \mathrm{N}$ uptake ratio than by limiting the growth rate itself. Specifically, reducing the maximum growth rate $\omega$ by $30 \%$ only delays the onset of the phytoplankton bloom by roughly half a month while - due to the effect of nutrient limitation - plankton concentrations and primary production are not significantly affected.

Reducing the actual growth rate by $30 \%$ also reveals no significant effect on the maximum primary production; however, the annually integrated primary production (Table 2) is reduced by $20 \%$ compared to the reference simulation. Nevertheless, similar to the experiment with $k_{\mathrm{S}_{\mathrm{i}}}=34.5 \mathrm{mmol} \mathrm{m}^{-3}$, maximum phytoplankton concentration in January is increased. Thus, if an observer takes a snapshot of an ecosystem like that, phytoplankton biomass may be even higher than in a scenario without iron limitation.

In contrast to that, the system's response to different $\mathrm{Si}: \mathrm{N}$ uptake ratios is much more pronounced. Annually integrated primary production in experiments with Si:N uptake ratios $r=8,4,2$, and 1 ranges from 38 to $166 \mathrm{~g} \mathrm{C} \mathrm{m}^{-2}$ year ${ }^{-1}$. Comparing this range to the modest response to a reduced maximum growth rate (Table 2) underlines the ecosystem's high sensitivity to different $\mathrm{Si}: \mathrm{N}$ uptake ratios. In the experiment with $r=1$, which - ac-
Table 2

Vertically integrated primary production in the reference simulation and the experiments with remineralization and varied sinking rates, varied half saturation constants $k_{\mathrm{S}_{i}}$, varied growth rates, varied $\mathrm{Si}: \mathrm{N}$ uptake ratios $r$ and modified annual cycles of mixed layer depth

\begin{tabular}{|c|c|}
\hline Experiment & $\begin{array}{l}\text { Vertically } \\
\text { integrated } \\
\text { primary } \\
\text { production } \\
{\left[\mathrm{g} \mathrm{C} \mathrm{m}^{-2} \text { year }^{-1}\right]}\end{array}$ \\
\hline Reference & 69 \\
\hline Remin.: sinking $1 \mathrm{~m} \mathrm{day}^{-1}$ & 83 \\
\hline Remin.: sinking $5 \mathrm{~m}$ day $^{-1}$ & 74 \\
\hline Remin.: sinking $10 \mathrm{~m} \mathrm{day}^{-1}$ & 72 \\
\hline$k_{\mathrm{S}_{\mathrm{i}}}=1 \mathrm{mmol} \mathrm{m}^{-3}$ & 80 \\
\hline$k_{\mathrm{S}_{\mathrm{i}}}=8 \mathrm{mmol} \mathrm{m}^{-3}$ & 61 \\
\hline$k_{\mathrm{S}_{\mathrm{i}}}=35.5 \mathrm{mmol} \mathrm{m}^{-3}$ & 29 \\
\hline Maximum growth rate $\omega$ reduced & 61 \\
\hline Actual growth rate $\sigma$ reduced & 53 \\
\hline $\mathrm{Si}: \mathrm{N}$ uptake ratio $r=1$ & 166 \\
\hline Si:N uptake ratio $r=2$ & 113 \\
\hline Si:N uptake ratio $r=8$ & 38 \\
\hline Offset of $h$ of $20 \mathrm{~m}$ & 69 \\
\hline Offset of $h$ of $40 \mathrm{~m}$ & 70 \\
\hline
\end{tabular}

cording to Hutchins and Bruland (1998) and Takeda (1998) - can be identified as a scenario without iron limitation, the maximum simulated biomass is 8 $\mu \mathrm{g} 1^{-1}$. This is comparable to experiments of Lancelot et al. (2000) in which a low Fe:C ratio was assumed. However, as plankton concentrations that high do not meet observations, we conclude that $r=1$ does not provide a realistic approach for the plankton community at the Antarctic Polar Front.

Results from experiments with an $\mathrm{Si}: \mathrm{N}$ uptake ratio of $r=2$ are closer to observations. Maximum phytoplankton concentrations of about $5 \mu \mathrm{g} \mathrm{1^{-1 }}$ compare well with an observed maximum phytoplankton concentration of $4.5 \mu \mathrm{g}^{-1}$ which was found in a watermass near the Polar Front, distinguished from the surroundings by higher concentrations of dissolved iron (de Baar et al., 1995; Bathmann et al., 1997).

Compared to the reference simulation, both experiments can be characterized by higher phyto- and zooplankton biomass, apparently overestimating typical plankton stocks near the Antarctic Polar Front.

In contrast to that, results from experiments with $r=8$, however, are quite similar to the experiment 
assuming a half saturation constant of $1.1 \mathrm{mmol}$ $\mathrm{m}^{-3}$. Silica depletion starts in spring and persists for an unrealistically long period. However, maximum concentrations of phytoplankton of about $2 \mu \mathrm{g} \mathrm{l^{-1 }}$ Chl $a$ are still in the range of observed values (Tréguer and Jacques, 1992).

From this study, we conclude that an Si:N uptake ratio between 2 and 4 is reasonable for the region of the Polar Front. Furthermore, we suggest that if varying iron supply causes variations of the $\mathrm{Si}: \mathrm{N}$ uptake ratio, this will have a much greater impact on primary production and the maximum phytoplankton stock than the modification of the maximum growth rate itself.

The experiments with different annual cycles of mixed layer depth show surprisingly low sensitivity of the annual primary production. Even in case the mixed layer does not get shallower than $60 \mathrm{~m}$, plankton concentrations are only little reduced. Apparently, the reduced light supply in the experiments with a deeper summer mixed layer is compensated for by a better nutrient supply. However, the zero-dimensional version of BIMAP provides only a crude approximation of hydrography near the Antarctic Polar Front. Mesoscale variability, reflected by upand downwelling, eddy pumping and meandering (e.g., Veth et al., 1997) cannot be described. Moreover, no information about horizontal variability is provided. Dafner and Mordasova (1994) pointed out that the horizontal gradient of silicate can reach 7.22 $\mu \mathrm{M} / \mathrm{km}$ in the Antarctic Polar Front. Nutrientlimited patches of phytoplankton might therefore be surrounded by plankton communities of totally different characteristics.

\section{Conclusions}

We have demonstrated that the zero-dimensional version of BIMAP is able to reproduce characteristic features of the annual cycles of phyto- and zooplankton growth and decay. Experiments with different half saturation constants for silicate uptake indicate that values in the range from 4 to $8 \mathrm{mmol} \mathrm{m}^{-3}$ allow for a realistic description of the plankton community near the Antarctic Polar Front. Experiments with different scenarios of iron limitation indicate that plankton blooms in the Southern Ocean are affected rather through an increased $\mathrm{Si}: \mathrm{N}$ uptake ratio than by a reduced maximum growth rate. Although $\mathrm{Si}: \mathrm{N}$ uptake ratios of 2 and 8 do not lead to totally unrealistic results, an Si:N ratio between 2 and 4 appears to be typical of phytoplankton in this region.

Modifications of the annual cycle of mixed layer depth reveal a surprisingly low response of the simulated ecosystem, so coupling BIMAP to a 3D mesoscale ocean model to fully cover effects of hydrography appears to be a natural step to an improved description of the ecosystem at the Antarctic Polar Front.

\section{Acknowledgements}

The authors wish to thank the reviewers for their helpful comments. Alfred-Wegner-Institut publication 1788.

\section{References}

Aksnes, D.L., 1996. Natural mortality, fecundity and development time in marine planktonic copepods - implications of behaviour. Mar. Ecol. Prog. Ser. 131, 315-316.

Bathmann, U.V., Scharek, R., Klaas, C., Dubischar, C.D., Smetacek, V., 1997. Spring development of phytoplankton biomass and composition in major water masses of the Atlantic Sector of the Southern Ocean. Deep-Sea Res. II 44 (1-2), 51-68.

Beckmann, A., Hellmer, H.H., Timmermann, R., 1999. A numerical model of the Weddell Sea: large scale circulation and water mass distribution. J. Geophys. Res. 104 (C10), $23375-$ 23391.

Biddanda, B.A., 1988. Microbial aggregation and degradation of phytoplankton-derived detritus in seawater: II. Microbial metabolism. Mar. Ecol. Prog. Ser. 42, 89-95.

Bidle, K.D., Azam, F., 1999. Accelerated dissolution of diatom silica by marine bacterial assemblages. Nature 397, 508-512.

Bracher, A.U., Tilzer, M.M., 2000. Underwater light field and phytoplankton absorbance in different zones of the Southern Ocean during early summer 1995/1996. Deep-Sea Res., special issue, in press.

Bracher, A.U., Kroon, B.M.A., Lucas, M.I., 1999. Primary production, physiological state and composition of phytoplankton in the Atlantic sector of the Southern Ocean. Mar. Ecol. Prog. Ser. 190, 1-16.

Brzezinski, M.A., 1985. The Si:C:N ratio of marine diatoms Interspecific variability and the effect of some environmental variables. J. Phycol. 21, 347-357.

Dafner, E.V., Mordasova, N.V., 1994. Influence of biotic factors on the hydrochemical structure of surface water in the Polar 
Frontal Zone of the Atlantic Antarctic. Mar. Chem. 45, 137148.

de Baar, H.J.W., 1994. von Liebig's Law of the minimum and plankton ecology (1899-1991). Prog. Oceanogr. 33, 347-386.

de Baar, H.J.W., de Jong, J.T.M., Bakker, D.C.E., Loescher, B.M., Veth, C., Bathmann, U., Smetacek, V., 1995. Importance of iron for plankton blooms and carbon dioxide drawdown in the Southern Ocean. Nature 373, 412-415.

DeMaster, D.J., Nelson, T.M., Harden, S.L., Nittrouer, C.A., 1991. The cycling and accumulation of biogenic silica and organic carbon in Antarctic deep-sea and continental margin environments. Mar. Chem. 35, 489-502.

Dubischar, C.D., Bathmann, U.V., 1997. Grazing impact of copepods and salps on phytoplankton in the Atlantic sector of the Southern Ocean. Deep-Sea Res. 44 (1-2), 415-434.

Eppley, R.W., 1972. Temperature and phytoplankton growth in the sea. Fish. Bull. 70, 1063-1085.

Evans, G.T., Parslow, J.S., 1985. A model of annual plankton cycles. Biol. Oceanogr. 3, 327-347.

Fasham, M.J.R., Ducklow, H.W., McKelvie, S.M., 1990. A nitrogen-based model of plankton dynamics in the oceanic mixed layer. J. Mar. Res. 48, 591-639.

Fasham, M.J.R., 1995. Variations in the seasonal cycle of biological production in subarctic oceans: a model sensitivity analysis. Deep-Sea Res. I 42 (7), 1111-1149.

Foxton, P., 1966. The distribution and life history of Salpa thompsoni (Foxton) with observations on a related species Salpa gerlachei (Foxton). Discovery Rep. 34, 1-116.

Fransz, H.G., Gonzalez, S.R., 1997. Latitudinal metazoan plankton zones in the Antarctic Circumpolar Current along $6^{\circ} \mathrm{W}$ during austral spring 1992. Deep-Sea Res. 44 (1-2), 395-414.

Fronemann, P.W., Perissinotto, R., McQuaid, C.D., Laubscher, R.K., 1995. Summer distribution of netphytoplankton in the Atlantic sector of the Southern Ocean. Polar Biol. 15, 77-84.

Gran, H.H., 1931. On the conditions for the production of plankton in the sea. Cons. Int. Explor. Mer, Rapp. P.V. Reun. 75, $37-46$.

Haidvogel, D.B., Wilkin, J.L., Young, R.E., 1991. A semi-spectral primitive equation ocean circulation model using vertical sigma and orthogonal curvilinear horizontal coordinates. J. Comput. Phys. 94, 151-185.

Hart, T.J., 1934. On the phytoplankton of the South-West Atlantic and the Bellingshausen Sea, 1929-1931. Discovery Rep. 8, $1-268$.

Hartmann, C., Hollmann, B., Kattner, G., Richter, K.-U., Terbrüggen, A., 1997. Nutrients, dissolved and particulate matter. In: Bathmann, U.V., Lucas, M., Smetacek, V. (Eds.), Reports on Polar Research: The Expedition Antarktis XIII/1-2 of the Research Vessel Polarstern in 1995/96. pp. 44-52.

Hense, I., Bathmann, U., Hartmann, C., Strass, V., Smetacek, V. et al., 1998. Spiny phytoplankton - slowing down the carbon pump in the Southern Ocean? EOS Trans., Am. Geophys. Union 79 (1), OS31C-10, Published as a Supplement.

Huntley, M.E., Zhou, M., Lopez, M.D.G., 1994. Calanoides acutus in Gerlache Strait, Antarctica: II. Solving an inverse problem in population dynamics. Deep-Sea Res. I 41, 209-227.

Huntley, M.E., Nordhausen, W., 1995. Ammonium cycling by Antarctic zooplankton in winter. Mar. Biol. 121, 457-467.
Hutchins, A.D., Bruland, K.W., 1998. Iron-limited diatom growth and $\mathrm{Si}: \mathrm{N}$ uptake ratios in a coastal upwelling regime. Nature 393, 561-564.

Jaques, G., 1983. Some ecophysiological aspects of the Antarctic phytoplankton. Polar Biol. 2, 27-33.

Jerlov, N.G., 1976. Marine Optics. Elsevier, Amsterdam, 231 pp.

Jitts, H.R., Morel, A., Saijo, Y., 1976. The relation of oceanic primary production to available photosynthetic irradiance. Aust. J. Mar. Fresh. Res. 27, 441-454.

Laevastu, T., 1960. Factors affecting the temperature of the surface layer of the sea. Commentat Phys.-Math. 25 (1).

Lancelot, C., Hannon, E., Becquevort, S., Veth, C., de Baar, H., 2000. Modeling phytoplankton blooms and carbon export production in the Southern Ocean: dominant controls by light and iron in the Atlantic sector in Austral spring 1992. Deep-Sea Res. I 47 (9), 1621-1662.

Laubscher, R.K., Perissinotto, R., McQuaid, C.D., 1993. Phytoplankton production and biomass at frontal zones in the Atlantic sector of the Southern Ocean. Polar Biol. 13, 471-481.

Lemke, P., Owens, W.B., Hibler, W.D., 1990. A coupled sea ice-mixed layer-pycnocline model for the Weddell Sea. J. Geophys. Res. 95 (C6), 9513-9525.

Lemke, P. et al., 1992. The expedition Antarktis X/4 of the research vessel Polarstern in 1992. Rep. Polar Res. 140, $1-90$.

Liebig, von J., 1840. Organic Chemistry and its Application to Agriculture and Physiology. Taylor and Walton, London.

Lorenzen, C.J., 1972. Extinction of light in the ocean by phytoplankton. J. Cons. 34, 262-267.

Löscher, B.M., de Baar, H.J.W., de Jong, J.T.M., Veth, C., Dehairs, F., 1997. The distribution of Fe in the Antarctic Circumpolar Current. Deep-Sea Res. II 44 (1-2), 143-187.

Lutjeharms, J.R.E., Walter, N.M., Allanson, B.R., 1985. Oceanic frontal systems and biological enhancement. In: Siegfried, W.R., Condy, P.R., Laws, R.M. (Eds.), Antarctic Nutrient Cycles and Food Webs. Springer Verlag, Berlin, pp. 11-21.

Martin, J.H., Fitzwater, S.E., 1988. Iron deficiency limits phytoplankton growth in the northeast Pacific subarctic. Nature 331, 341-343.

Minas, H.J., Minas, M., 1992. Net community production in "High Nutrient-Low Chlorophyll" waters of the tropical and Antarctic Oceans: grazing versus iron hypothesis. Oceanol. Acta 15, 145-162.

Nelson, D.M., Gordon, L.I., 1982. Production and pelagic dissolution of biogenic silica in the Southern Ocean. Geochim. Cosmochim. Acta 46, 491-501.

Nelson, D.M., Smith, W.O. Jr., 1986. Phytoplankton bloom dynamics of the western Ross Sea ice edge: II. Mesoscale cycling of nitrogen and silicon. Deep-Sea Res. 33 (1), 13891412.

Nelson, D.M., Tréguer, P., 1992. Role of silicon as a limiting nutrient to Antarctic diatoms: evidence from kinetic studies in the Ross Sea ice-edge zone. Mar. Ecol. Prog. Ser. 80, 255-264.

Nelson, D.M., Tréguer, P., Brzezinski, M.A., Leynaert, A., Quéguiner, B., 1995. Production and dissolution of biogenic silica in the ocean: revised global estimates, comparison with regional data and relationship to biogenic sedimentation. Global Biogeochem. Cycle 9 (3), 359-372. 
Paffenhoefer, G.A., Harris, R.P., 1976. Feeding, growth and reproduction of the marine planktonic copepod Pseudocalanus elongatus. J. Mar. Biol. Assoc. U. K. 56, 327-344.

Peters, E., Thomas, D.N., 1996. Prolonged darkness and diatom mortality: I. Marine Antarctic species. J. Exp. Mar. Biol. Ecol. 207, 25-41.

Pondaven, P., Fravalo, C., Ruiz-Pino, D., Tréguer, P., Quéguiner, B., Jeandel, C., 1998. Modelling the silica pump in the permanently open ocean zone of the Southern Ocean. J. Mar. Syst. 17, 587-619.

Pondaven, P., Ruiz-Pino, D., Druon, J.N., Fravalo, C., Tréguer, P., 1999. Factors controlling silicon and nitrogen biogeochemical cycles in high nutrient, low chlorophyll systems (the Southern Ocean and the North Pacific): comparison with a mesotrophic system (the North Atlantic). Deep-Sea Res. 46, 1923-1968.

Quéguiner, B., Tréguer, P., Peeken, I., Scharek, R., 1997. Biogeochemical dynamics and the silicon cycle in the Atlantic sector of the Southern Ocean during austral Spring 1992. Deep-Sea Res. 44 (2), 69-90.

Sakshaug, E., Holm-Hansen, O., 1984. Factors governing pelagic production in polar oceans. In: Holm-Hansen, O., Bolis, L., Gilles, R. (Eds.), Marine Phytoplankton and Productivity. Lect. Notes Coastal Estuarine Stud. 8. Springer Verlag, Berlin, pp. $1-18$.

Schnack, S.B., 1985. Feeding by Euphausia superba and copepod species in response to varying concentrations of phytoplankton. In: Siegfried, W.R., Condy, P.R., Laws, R.M. (Eds.), Antarctic Nutrient Cycles and Food Webs. Springer Verlag, Berlin, pp. 311-323.

Shiomoto, A., Ishii, H., 1995. Distribution of biogenic silica and particulate organic matter in coastal and oceanic surface waters off the South Shetland Islands in summer. Polar Biol. 15, $105-113$

Smetacek, V., Passow, U., 1990. Spring bloom initiation and Sverdrup's critical-depth model. Limnol. Oceanogr. 35 (1), 228-234.

Smetacek, V., de Baar, H.J.W., Bathmann, U.V., Lochte, K., Rutgers van der Loeff, M.M., 1997. Ecology and biogeochemistry of the Antarctic Circumpolar Current during austral spring: a summary of Southern Ocean JGOFS cruise ANT X/6 of R.V. Polarstern. Deep-Sea Res. II 44 (1-2), 1-21.

Smetacek, V., 1999. Diatoms and the ocean carbon cycle. Protist 150, 25-32.

Sommer, U., 1986. Nitrate- and silicate-competition among Antarctic phytoplankton. Mar. Biol. 91, 345-351.

Sommer, U., 1991. Comparative nutrient status and competitive interactions of two Antarctic diatoms (Corethron criophilum and Thalassiothrix antarctica). J. Plankton Res. 13, 61-75.

Song, Y., Haidvogel, D.B., 1994. A semi-implicit ocean circulation model using a generalized topography-following coordinate. J. Comput. Phys. 115, 228-244.

Steele, J.H., Henderson, E.W., 1992. The role of predation in plankton models. J. Plankton Res. 14, 157-172.

Sverdrup, H.U., 1953. On conditions for the vernal blooming of phytoplankton. J. Cons., Cons. Int. Explor. Mer. 18, 287-295.

Takeda, S., 1998. Influence of iron variability on nutrient consumption ratio of diatoms in oceanic waters. Nature 393, 774-777.

Tréguer, J., Kamatami, A., Gueneley, S., Quéguiner, B., 1989. Kinetics of dissolution of Antarctic diatoms frustules and the biogeochemical cycle of silicon in the Southern Ocean. Polar Biol. 9, 397-403.

Tréguer, J., Jacques, G., 1992. Dynamics of nutrients and phytoplankton, and fluxes of carbon, nitrogen and silicon in the Antarctic Ocean. Polar Biol. 12, 149-162.

Veth, C., Peeken, I., Scharek, R., 1997. Physical anatomy of fronts and surface waters in the ACC near the $6^{\circ} \mathrm{W}$ meridian during austral spring 1992. Deep-Sea Res. 44 (1-2), 23-50.

Williams, P.J., 1990. The importance of losses during microbial growth: commentary on the physiology, measurement and ecology of the release of dissolved organic material. Mar. Microb. Food Webs 4, 175-206.

WOCE Hydrographic Program Office, http://whpo.ucsd.edu/ index.html.

Zillmann, J.W., 1981. A study of some aspects of the radiation and heat budgets of the southern hemisphere oceans, Meteorological Study 26 Bureau of Meteorology, Dept. of the Interior, Canberra, Australia, 526 pp. 